\title{
DISPERSAL AND ESTABLISHMENT OF HUON PINE (LAGAROSTROBOS FRANKLINII)
}

\author{
by $A$. Shapcott
}

(with seven figures and four tables)

SHAPCOTT, A.J., 1991 (20:xii): Dispersal and establishment of Huon pine (Lagarostrobos franklinii). Pap. Proc. R. Soc. Tasm. 125: 1726. https://doi.org/10.26749/rstpp.125.17 ISSN 0080-7403. Department of Parks, Wildlife and Heritage, GPO Box 44A,

Hobart, Tasmania, Australia 7001 and Department of Plant Science, University of Tasmania GPO Box 252C, Hobart,

Tasmania, Australia 7001

Huon pine had a mast year in 1989 resulting in massive seedfall. It was found that Huon pine had extremely limited lateral seed dispersal by wind, although the chances of dispersal by water appear extremely good, due to its flocation capabilities. Green rosellas (Platycercus caledonicus Gmelin) were observed feeding on the seed and may play some role both as predators and dispersers of seed. A low percentage of successful germination was achieved and germination rate was slow. Seedlings appear to establish mostly on soil substrates but also occur on logs and trunks. Colonisation, even downstream, can take a considerable period of time and may partly explain the restricred distribution of Huon pine. The implications of these results for conservation and management are discussed.

Keywords: Huon pine, Lagarostrobos franklinii, Podocarpaceae, dispersal, seed germination, seedfall, colonisation.

\section{INTRODUCTION}

Huon pine (Lagarostrobos franklinii (Hook f.) Quinn) is a Tasmanian endemic conifer with restricted distribution in the southwestern part of the state. It is highly prized for its timber and has been subjected to logging for 180 years (Gibson 1986). Huon pine is extremely slow growing but long-lived (Francey et al. 1984). Its population numbers have been severely reduced due to human activities (Gibson 1986). An understanding of its reproductive, dispersal and establishment capabilities will contribute to assessments of its requirements for long-term viability and hence its conservation.

The extant distribution of most Huon pine stands close to rivers, creeks or drainage lines, where the species often forms a thin fringe on the banks (Peterson 1990), has led Millington et al. (1979) and Gibson (1986) to suggest that lateral dispersal of Huon pine is poor and that most dispersal is down rivers or moving water bodies. Where it occurs over wider areas, for example on river flats, on slopes and in limestone sink holes (e.g. Pedley et al. 1980), it is associated with moist, often boggy conditions, in locally fire-protected areas of high rainfall (Gibson 1988). Some evidence of expansion of Huon pine stands into previously fired areas has been recorded by Davies (1983) and Gibson (1986).

Huon pine is known to reproduce vegetatively as well as sexually (Millington et al. 1979). The vegetative reproduction observed offered only limited dispersal opportunities since propagules were limited to the extent of the root system or the length of the fallen trunk of the parent tree. Davies (1983) and Pedley et al. (1980) have speculated that fallen twigs may lodge, take root and shoot, and that these twigs may be dispersed by water, particularly by floods, to a suitable site. However, these seem to be rare events and most regrowth along rivers appears to result either from local vegetative reproduction or from seedlings.

Huon pine is mostly dioecious (Quinn 1982) and its reproductive activity is commonly thought to be episodic, with years of synchronised high reproductive activity (mast years) occurring approximately every 5-7 years. Such a mast year occurred in the $1988-89$ season. This season also coincided with high reproductive activity in many other Tasmanian rainforest species.

Many aurhors (e.g. Read \& Hill 1983, Harman \& Franklin 1989) have suggested that logs and trunks may form major sites for seedling establishment. The lack of such suitable germination sites may consequently limit establishment possibilities.

This paper reports the results of an investigation into the pattern and timing of seedfall in a mast year in Huon pine. In addition, several vectors of seed dispersal were investigated, including lateral dispersal by wind or by the green rosella (Platycercus caledonicus Gmelin), and the potential for longdistance dispersal by water. The paper also describes experiments in germination under optimum conditions in the glasshouse and field observations differentiating the relative importance of habitat for seedling establishment. Finally, downstream colonisation by Huon pine at Condominium Creek is recorded and an approximate time frame for this process determined.

\section{MATERIALS AND METHODS}

\section{Seedfall and Dispersal}

Seed traps were set up at two sites in order to investigate seedfall and seed dispersal. One site was at Riveaux Creek (lat. $43^{\circ} 11^{\prime} 3^{\prime \prime}$, long. 146² $\left.40^{\prime} \mathrm{E}\right)$ near the Picton River, at the eastern limits of the distribution of Huon pine. The other was at Teepookana (lat. $42^{\circ} 14^{\prime} \mathrm{S}$, long. $145^{\circ} 27^{\prime} \mathrm{E}$ ) close to Macquarie Harbour, near the western edge of its distribution. The traps were of two types but both collected over a $1 \mathrm{~m}^{2}$ area. The first type was made of galvanised iron, had a circular mouth and was funnel shaped. The second type was made of sailcloth and PVC piping and the funnel had a square mouth. Both had a sieved bucket attached to the base of the funnel to collect seed, and an open stocking leg was placed in the bucket to act as an appropriately sized filter and collection bag. The traps were mounted on wooden stakes. The seed was collected approximately monthly. The content of the stockings were air dried, if necessary, prior to sieving to 

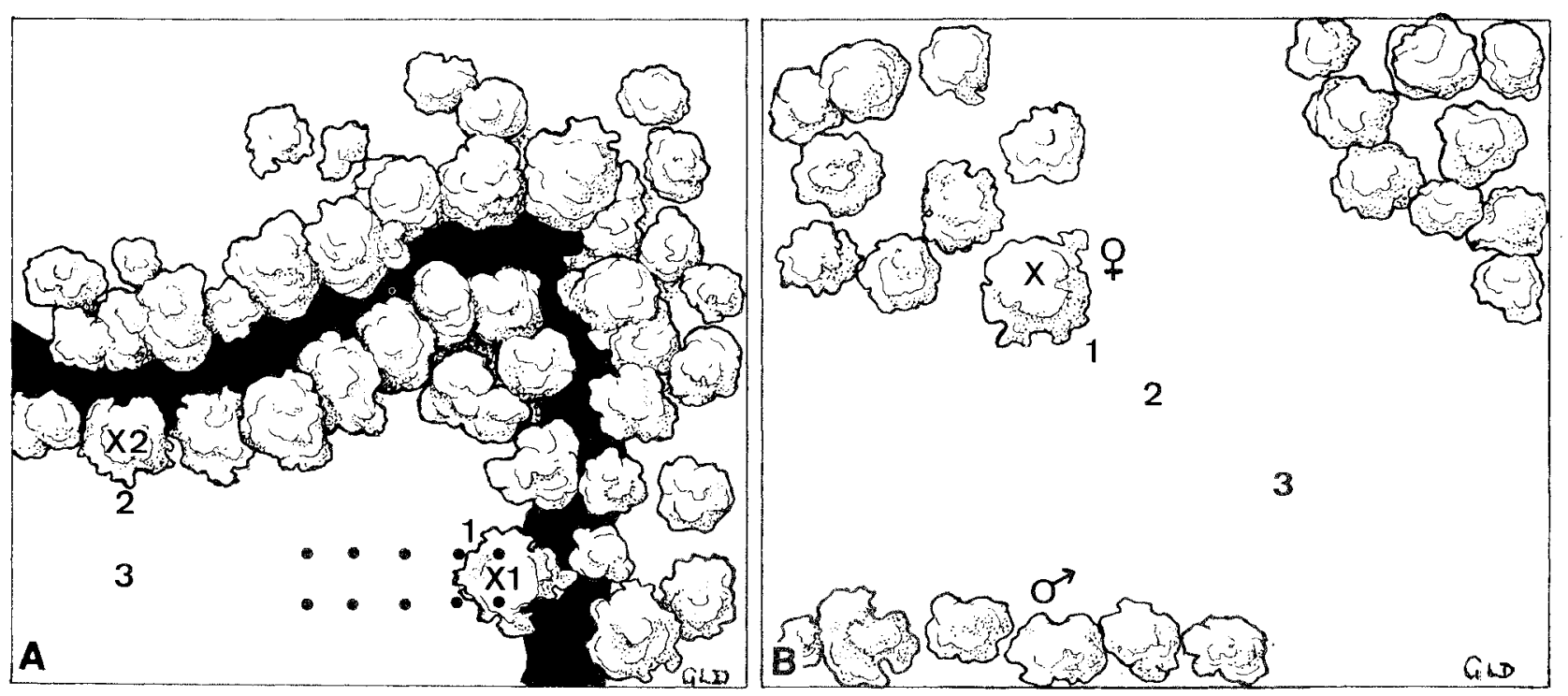

FIG. 1 - The spatial relationship between Huon pine seed traps, seed trees and Huon pine dominated forest at (A) the Riveaux Creek and (B) the Teepookana study sites. The positions of the seed traps are labelled by (1) (2) and (3). The site of quadrats for soillitter samples are also shown $(\bullet)$. X- seed source tree at Teepookana. XI - tree 1 at Riveaux Creek. X2 - tree 2 at Riveaux Creek.

remove as much extraneous material as was possible. This sieved sample was weighed and a sub-sample taken and weighed. The subsample (1-2 g) was then sorted and seed counted. Undersized seed was removed at this stage. Quantities of seed were extrapolated from these values.

At Riveaux Creek three traps were set up; two of these were located directly underneath the outer branches of each of two female cone-bearing trees. The third trap was located approximately one tree height (approx. $20 \mathrm{~m}$ ) from both of the trees, as shown in figure $1 \mathrm{~A}$. The prevailing wind direction was mostly from tree 1 to trap 3 (i.e. from the southwest); tree 1 was in the position furthest upstream in the stand and was one of the large old dominant trees, while tree 2 was smaller. Both trees were heavily laden with seedbearing cones.

At Teepookana three seed traps were set up at increasing distances from a fairly isolated seed-bearing tree in an area that was cleared and exposed. Trap 1 was located directly under the crown, while trap 2 was one tree height and trap 3 was three tree heights downwind of the tree (fig. 1B). The tree used as a source tree had a much smaller crown than the trees at Riveaux Creek.

Samples of the surface soil and litter were taken from two parallel transects from tree 1 at Riveaux Creek in November 1989. Quadrats, $0.24 \mathrm{~m} \times 0.24 \mathrm{~m}$, were marked and, using a trowel, scraped bare of surface soil, litter and moss, which were collected. These samples were later flushed with water through a sieve, air dried and resieved, and the number of Huon pine seeds was estimated in the same manner as for the seed traps. Quadrats were located at mid-canopy, at the edge of canopy, and then at $4 \mathrm{~m}$ intervals to $12 \mathrm{~m}$ (fig. 1A). Seed numbers were used to indicate lateral seed dispersal and the amount of seed still on the ground several months after scedfall.

\section{Green Rosellas}

Green rosellas (Platycerus caledonicus) feeding on Huon pine were noted on regular visits to Riveaux Creek. The feeding behaviour and trees visited were noted by direct observation and ground evidence. The period of feeding was recorded, i.e. first observation and monthly observations till activity ceased.

\section{Seed Flotation}

An experiment was carried out to investigate the period of time that Huon pine seeds can remain afloat. Three replicates were made, each containing 1000 seeds in a jar half-filled with tap water, with a porous cloth fastened to and covering the opening. The seeds were swirled approximately once per day, and every three to four days the water was changed by draining through the cloth and refilling. These processes ensured that the seeds were not floating due to surface tension and prevented algal development. The numbers of floating and submerged seeds were counted at regular intervals. The seeds used were collected from tree $l$ at Riveaux Creek. Following the experiment, the seeds that remained floating, a sample of submerged seeds and a sample of similar aged airdried seeds were subjected to a squash test in order to monitor embryo deterioration. Samples of submerged seeds and of air-dried sced were planted to test germination.

\section{Seed Germination and Establishment}

Fresh seed collected from a single tree at Riveaux Creek was used to set up a combination of germination experiments. Four replicates of 100 seeds were used for each combination of treatments. Three temperature treatments were set up as follows: constant $10^{\circ} \mathrm{C} ; 20^{\circ} \mathrm{C}$; and $10^{\circ}-25^{\circ} \mathrm{C}$ diurnal fluctuation. Temperature treatments were conducted in growth cabinets with a 14-hour photoperiod; germination was also examined under glasshouse conditions with no artificial light. Seven physical treatments were carried out under all four temperature regimes (fig. 2): these were "untreated"; "damaged" by pricking with a needle; "soaked" in tap water for one week prior to sowing; "stratified for 


\section{GLASSHO!JSE}

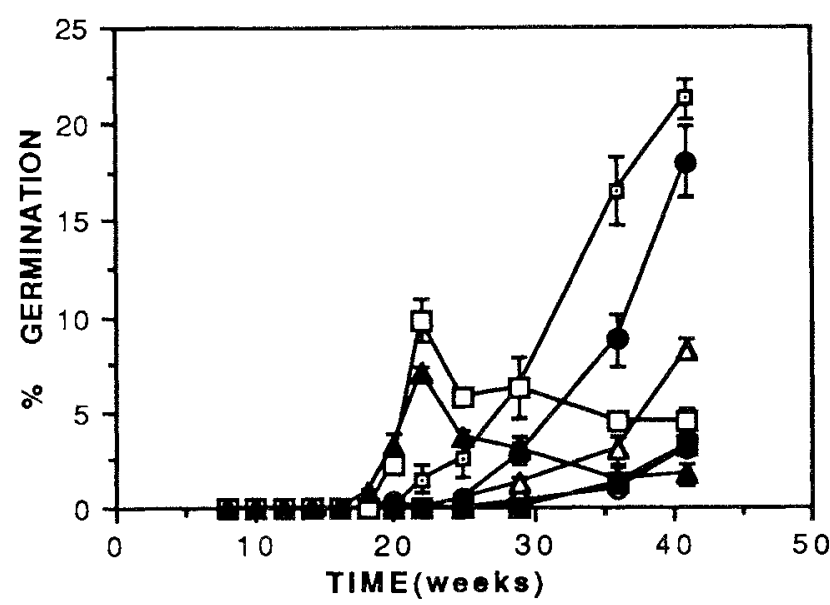

$10-25 \mathrm{C}$
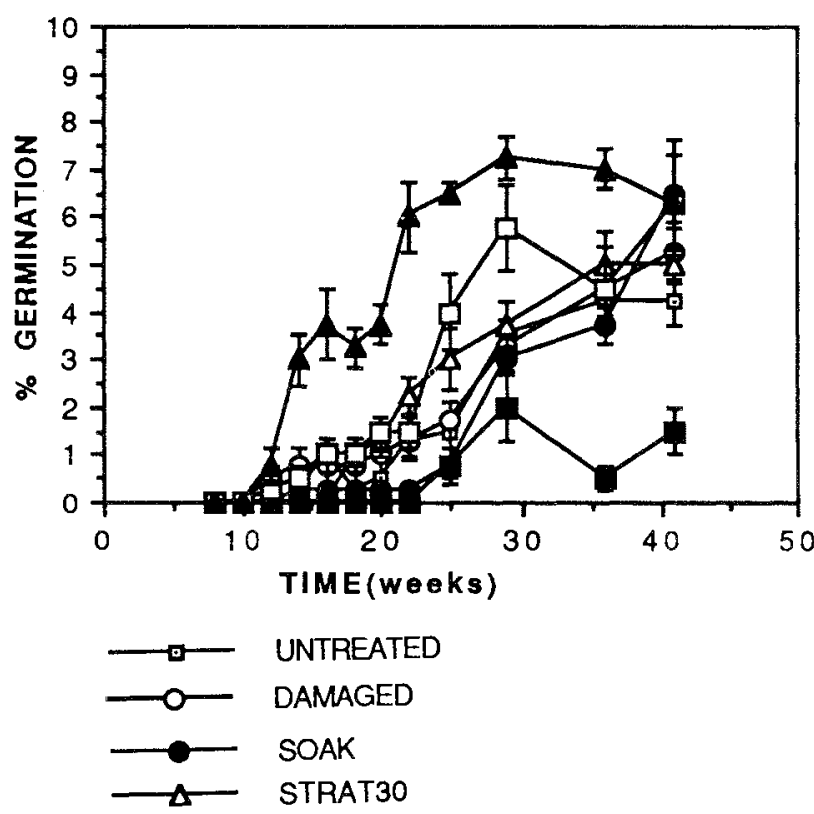

$10 \mathrm{C}$

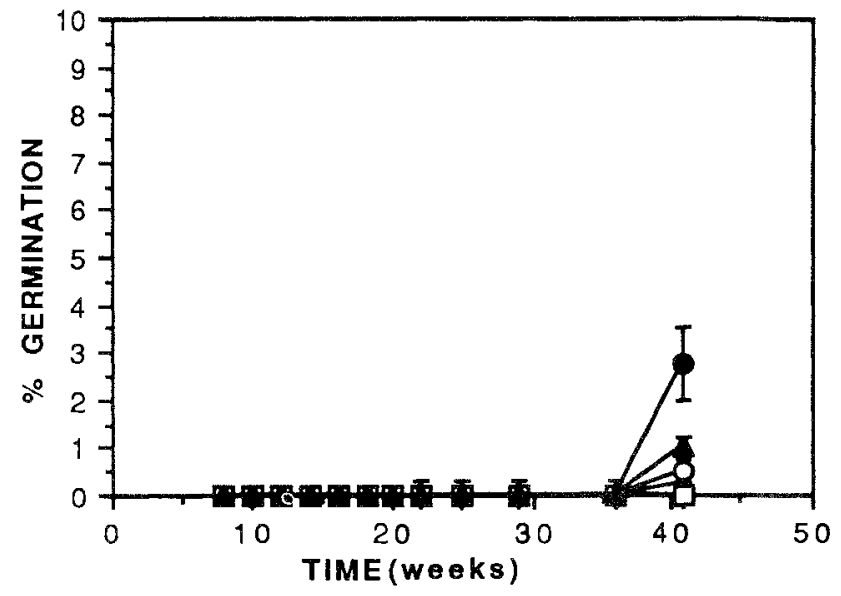

$20 \mathrm{C}$

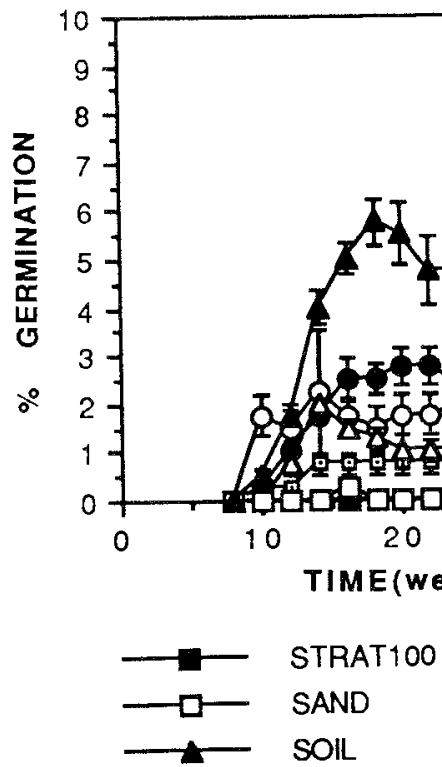

FIG. 2 - Mean percentage germination of Huon pine seeds over time (weeks), under seven physical treatments, and in four temperature regimes.

30 days" in a cold room $\left(4^{\circ} \mathrm{C}\right)$; "stratified for 100 days"; sown in "sand"; sown in river "soil". All seeds were sown in clear plastic containers with lids. Except for the "sand" and "soil" treatments, they were sown on to filter paper overlying a layer of cotton wool. All seeds were dusted with "Thirium" fungicide prior to planting. Seeds were kept moist by regular watering with tap water.

The experiment ran from April 1989 until March 1990 and was scored fortnightly until week 22 and then as indicated (fig. 2). At each scoring the seeds were recorded in three categories: (1) open seed, i.e. the seed coat had split open; (2) emergence of root or hypocotyl from the seed; (3) cotyledons present and expanded. There was some mortality. The results of stages 2 and 3 were pooled for some analyses (fig. 2), since these represented an assessment of successful germination.

The site at Riveaux Creek was visited regularly (approximately monthly) to monitor other studies not included here. During these visits the site was monitored for the appearance of seedlings.
The number of seedlings established on logs or trunks (including logs and trunks of other species) and ground (soil, moss and rock) was recorded in the field from 19 sites, as part of a larger survey of stand structure and genetic variation (Shapcott 1991). At each site wide transects, which encompassed much of the stand, were surveyed for all Huon pine, as described below at Condominium Creek; the number, location and substrate of seedlings were recorded. Isolated individual stems less than $1 \mathrm{~m}$ tall were classified as seedlings but it was not possible in all cases to determine if these were actual seedlings or were vegetative growth from roots or trunks. Major excavations were not usually possible or desirable. As a consequence seedling numbers may have been overestimated.

\section{Colonisation down Condominium Creek}

Condominium Creek (lat. 42 $57^{\prime} 20^{\prime \prime} S$, long. 146 $23^{\prime} \mathrm{E}$ ) flows southwest from Mr Anne. The creek was surveyed 
upstream from its intersection with the Scotts Peak Road until the first Huon pines (in this case seedlings) were found. From there all Huon pine plants and their location in relation to the creek were recorded and the following measurements taken; height, diameter and sex (if reproductively active). The stand was surveyed and sampled until it ended. There may have been trees further up the creek but these were not investigated. Nearly all of the Huon pine population occurs on the northern side of the creek, with more trees on the southern side only at the upper, older end of the stand. Buttongrass (Gymnoschoenus sphaerocephalus (R. Br.) Hook. f.) and Leptospermum-dominated heath dominates the southern bank in most places.

\section{RESULTS}

\section{Seedfall and Dispersal}

The trees at Riveaux Creek shed approximately 50000 sceds $/ \mathrm{m}^{2}$, whereas at Teepookana seedfall was only 2200 seeds $/ \mathrm{m}^{2}$ (table 1). The seeds were collected for a longer period at Riveaux Creek and the trees had larger crowns, which may account for some of the discrepancy between sites. Both sites show a pattern of limited lateral seed dispersal. No seeds were found at one tree height distance at Teepookana and only eight were found over the six months of collection at this distance from trees at Riveaux Creek.

The quantity and timing of seedfall in traps 1 and 2 at Riveaux Creek are shown in figure 3 below. Seedfall started in February; the peak period of seedfall occurred around eight weeks later in early April, after which seed continued to fall at a reduced rate. The last seed counts were made six months from onset of seedfall, though the last of the seed was still dropping in December. The timing and amount of seedfall for the two trees at Riveaux Creek were similar.

The two transects designed to examine the seed stored in the soil showed similar patterns of seed dispersal, as indicated by the results from the seed traps. Although more seeds were collected from transect 1 , very few seeds were found at $12 \mathrm{~m}$ from the canopy edge (fig. 4).

The soil samples under the canopy contained approximately $20 \%$ of the seed numbers recorded in the seed traps on a per unit area basis. Although the soil seed numbers were obtained by a different method (i.e. not seed traps) and hence the results were not expected to be directly comparable, they still suggest that substantial seed loss has occurred in six months.

TABLE 1

Total of Huon pine seeds collected in February-November 1989

\begin{tabular}{lll}
\hline Site & $\begin{array}{c}\text { Seedtrap no. and } \\
\text { distance }(\mathrm{m}) \\
\text { from source tree }\end{array}$ & \multicolumn{1}{c}{ Seeds $/ \mathrm{m}^{2}$} \\
Riveaux Creek & $1(0)$ & $5.2 \times 10^{4}$ \\
& $2(0)$ & $4.8 \times 10^{4}$ \\
& $3(25 \& 15)$ & 8 \\
Teepookana & $1(0)$ & $2.2 \times 10^{3}$ \\
& $2(20)$ & 0 \\
& $3(60)$ & 0 \\
\hline
\end{tabular}

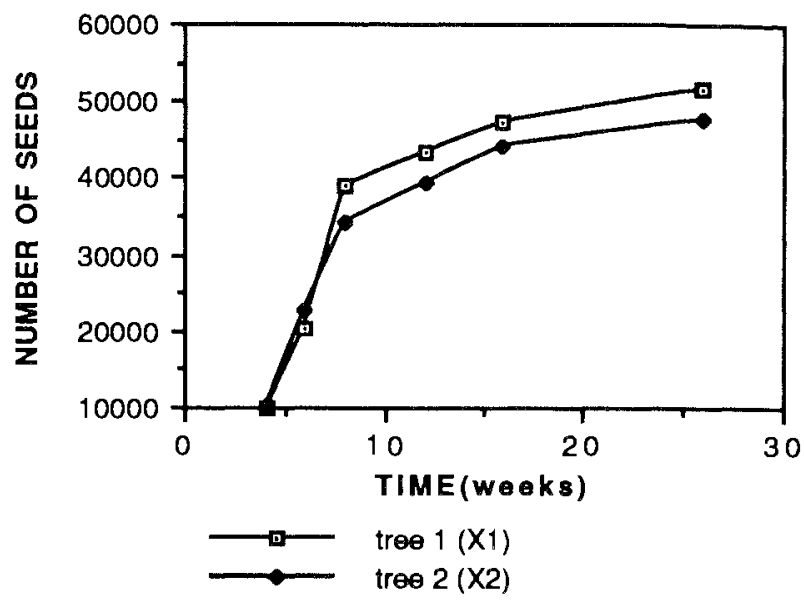

FIG.3 - The cumulative Huon pine seedfall in two $1 \mathrm{~m}^{2}$ seed traps in relation to time at Riveaux Creek.
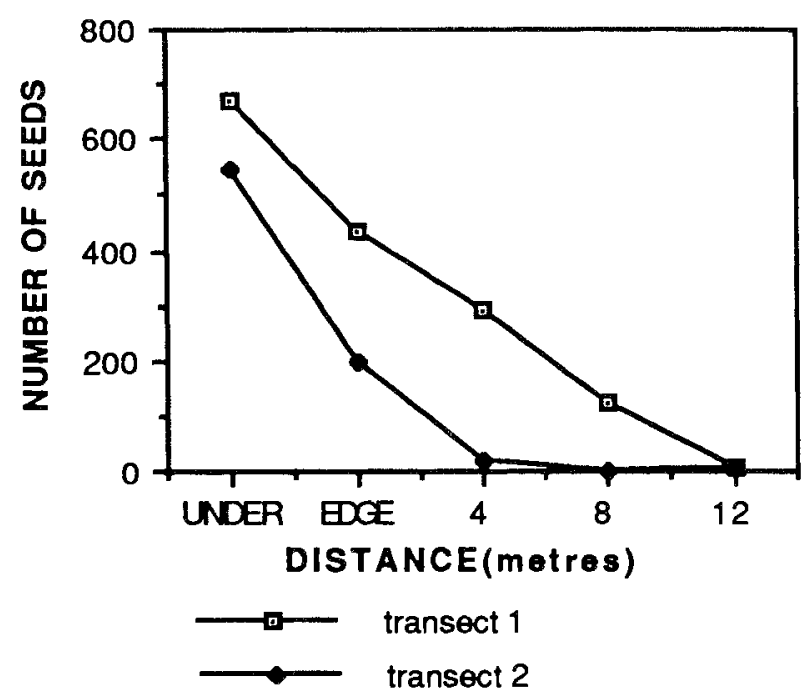

FIG. 4- The number of Huon pine seeds in soillitter samples $\left(576 \mathrm{~cm}^{2}\right)$ against the distance along two parallel transects which extended out from under the canopy of Huon pine seed source tree (X1). (See fig. 1A.) (EDGE-edge of seed tree canopy (approx $4 \mathrm{~m}$ from first measurement): UNDER - under the middle of the seed tree canopy and at the start of the transect.)

\section{Green Rosellas}

Green Rosellas (Platycercus caledonicus) were first observed feeding on Huon pine at Riveaux Creek in April 1989. Sightings and evidence of their presence continued until December 1989. Prior to the initial observation no evidence of their presence was noticed. Such evidence consists of broken terminal branchlets found beneath the trees (Brown 1984). The commencement of feeding corresponded to the peak seedfall and the end of the warmerweather. All branchlets found on the ground until October bore mature female cones. This, together with direct observations, suggests that they were feeding on the seeds. From October 1989 (coinciding with maturation of young male cones and the end of the 1988-89 seed crop) green rosella activity seemed to move to the male trees where branchlets bearing mature male cones were found beneath male trees. Scattered evidence of feeding by green rosellas was observed at several sites from seedfall onwards during fieldwork. These observations confirm the suggestion by Gibson (1986) that green rosellas feed on 
Huon pine. They appear to eat mature sceds and pollen. It is unknown what the effect of their gut is on the seeds. Green rosellas are known to carry food up to $100 \mathrm{~m}$ to feed (P. Brown, pers. comm.) and this could offer some lateral dispersal possibilities for Huon pine. There is some possibility that vegetative material (shoot tips) could also be dispersed in this manner.

\section{Seed Flotation}

Approximately $50 \%$ of the seed floated for one month and $5 \%$ stayed afloat for at least two months (fig. 5). If seed can stay afloat for such long periods of time, the potential distances for dispersal by water are enormous, provided viability is retained.

Squash tests for embryo deterioration indicated that seeds were usually still healthy after two months soaking (table 2) regardless of whether they remained floating or were submerged. Dry-stored seed from the same batch had a very high percentage of healthy embryos. Tests on submerged seed indicate that soaked seeds start germination marginally faster than dry-stored seed.

\section{Germination and Establishment}

In general, germination was low, with most treatments resulting in less than $20 \%$ overall germination and less than $10 \%$ of germinants progressing to the second (root) or third (expanded cotyledon) stages. The highest germination rate (22.75\% total germination) was obtained after wcek 41 by untreated seeds in the glasshouse(fig. 2). The earliest germination started at week 10 in all temperatures except for $10^{\circ} \mathrm{C}$. Very little germination occurred in the $10^{\circ} \mathrm{C}$ treatments and that which did occurred after week 36 (fig. 2). The earliest seedlings (stages 2 and 3 ) appeared in week 10 and were from the $20^{\circ} \mathrm{C}$ and damaged treatment combination. In the $20^{\circ} \mathrm{C}$ and $10^{\circ}-25^{\circ} \mathrm{C}$ temperatures, the "soil" treatment was the most successful (fig. 2). Initially the "soil" and "sand" treatments did well in the glasshouse but towards the end of the experiment (weeks 36-41) the "untreated" and "soaked" treatments surpassed them. Stratification did not improve germination.

From the field records at Riveaux Creek, germination in the field began between week 29 and week 36 of the experiment (January/February) and corresponded to the rapid increase of germination in some glasshouse treatments. Germination in the field at Riveaux Creek the following year occurred during the same specific time period and the

TABLE 2

Percentage of viable embryos* in Huon pine seed used for the seed flotation experiment

\begin{tabular}{lcr}
\hline & $\begin{array}{r}\text { Number of } \\
\text { seeds tested }\end{array}$ & $\begin{array}{r}\text { Viable seeds } \\
\%\end{array}$ \\
\hline Floaring seeds & 18 & 78 \\
Submerged seeds & 20 & 80 \\
Air-dry stored seeds & 100 & 99
\end{tabular}

* Determined by squash tests.

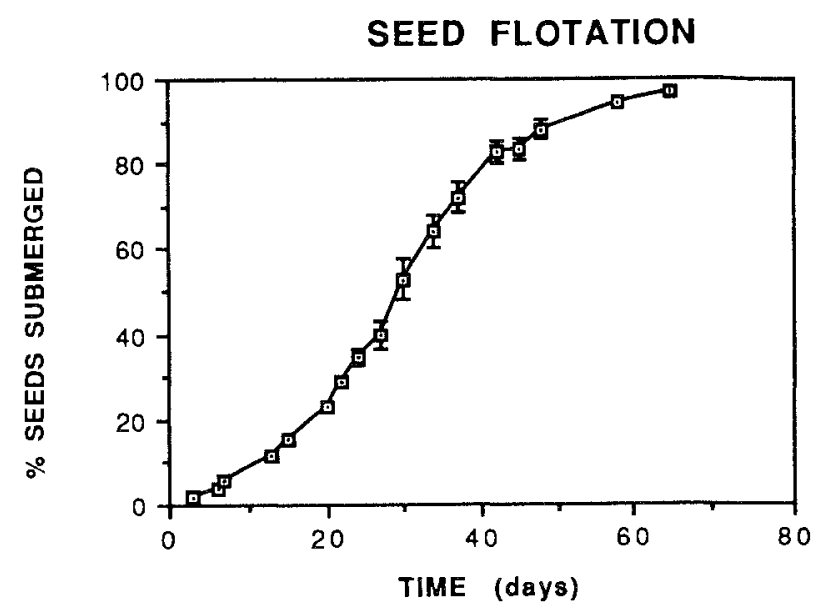

Fig. 5 - The percentage of seeds no longer floating versus time. The percentages are mean values of three replicates of 1000 seeds, the standard error bars are indicated.

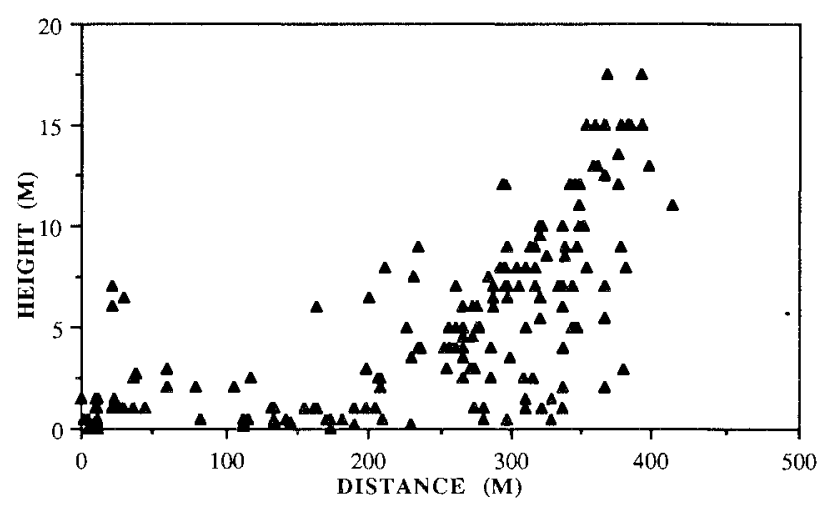

FIG. 6- The height of Huon pine plants is plotted against the distance up the Huon pine transect (fig. 7). Each point represents a Huon pine plant. Distances as in figure 7.

seed must have been from the same seed set. In general, these experiments have decreased the time before germination began, compared to the field situation. The effects of physical treatments on germination was not constant between the temperature treatmenrs.

Approximately $20 \%$ of seedlings were found on logs or living trunks. Logs thus make up a sizeable part but minority of establishment sites (table 3).

\section{Colonisation down Condominium Creek}

Figure 7 illustrates the relative size and abundance of Huon pine up Condominium Creck. Small seedlings and suckers were found, mostly along the bank, from the first occurrence. However, there is a distinct size-class gradation from taller trecs upstream to smaller ones further down (figs 6 and 7). If conservative age estimates are made from diameter measurements (Gibson 1986) it can be estimated that colonisation to $400 \mathrm{~m}$ downstream has taken at least 200 years. 
TABLE 3

Comparison of number of huon pine seedlings found on different substrates

\begin{tabular}{|c|c|c|c|c|}
\hline Site & $\begin{array}{l}\text { No. on logs } \\
\text { or trunks }\end{array}$ & $\begin{array}{l}\text { No. on soil, } \\
\text { sand or rock }\end{array}$ & Total & $\begin{array}{c}\text { Area } \\
\text { sampled } \\
\left(\mathrm{m}^{2}\right)\end{array}$ \\
\hline Newall & 9 & 12 & 21 & 4560 \\
\hline Stanley & 14 & 65 & 79 & 2100 \\
\hline Greystone & 20 & 29 & 49 & 1200 \\
\hline Pine Creek & 0 & 13 & 13 & 4800 \\
\hline Riveaux Creek & 185 & 2 & 187 & 1220 \\
\hline Denison & 10 & 4 & 14 & 3060 \\
\hline Gordon & 40 & 0 & 40 & 200 \\
\hline Teepookana & 1 & 5 & 6 & 3936 \\
\hline Frenchmans Cap & 22 & 0 & 22 & 216 \\
\hline Picton & 88 & 0 & 88 & 1150 \\
\hline Pieman & 20 & 4 & 24 & 6682 \\
\hline Gilbert Leitch & 5 & 12 & 17 & 1196 \\
\hline Anne & 8 & 0 & 8 & 880 \\
\hline Tahune & 71 & 41 & 112 & 1092 \\
\hline Condominium Creek & 71 & 1 & 72 & 6210 \\
\hline Huon & 138 & 4 & 142 & 695 \\
\hline King & 12 & 0 & 12 & 975 \\
\hline Junction Creek & 25 & 23 & 58 & 2565 \\
\hline Eagle Creek (Gordon) & 85 & 27 & 112 & 2042 \\
\hline Total & 824 & 242 & 1066 & 44779 \\
\hline Total \% of seedings & 77.3 & 22.7 & & \\
\hline
\end{tabular}

TABLE 4

Summary of seedfall data* from a variety of high yielding tree species (converted to the number of seeds $/ \mathrm{m}^{2}$ )

\begin{tabular}{|c|c|c|}
\hline Species & Seed no. $/ \mathrm{m}^{2}$ & Author \\
\hline Dendrocalamus strictus ${ }^{\dagger}$ & $1.3 \times 10^{5}$ & Janzen (1976) \\
\hline Lagarostrobos franklinit & $5.0 \times 10^{4}$ & Shapcott \\
\hline Nothofagus cunninghamin & $1.3 \times 10^{4}$ & Howard (1973) \\
\hline Athrotaxis selaginoides & $7.7 \times 10^{3}$ & Berrigan (1982) \\
\hline Eucalyptus delegatensis & $4 \times 10^{3}$ & O'Dowd \& Gill (1984) \\
\hline Macrozamia communist & $3.5 \times 10^{3}$ & Ballardie \& Whelan (1986) \\
\hline \multicolumn{3}{|l|}{ Picea sitchensist } \\
\hline Tsuga heterophylla & $3.5 \times 10^{3}$ & Harman \& Franklin (1989) \\
\hline Atherosperma moschatum & $1.2 \times 10^{3}$ & Hickey et al. (1982) \\
\hline Dacrydium cupressinum ${ }^{\dagger}$ & $1.2 \times 10^{3}$ & Ogden (1985) \\
\hline Eucryphia lucidas & $8 \times 10^{2}$ & Hickey et al. (1982) \\
\hline
\end{tabular}

* Collected from the literature.

$\dagger$ Mast seed years.

$\ddagger$ From the present study.

I Tasmanian species. 


\section{Condominium Creek Transect}
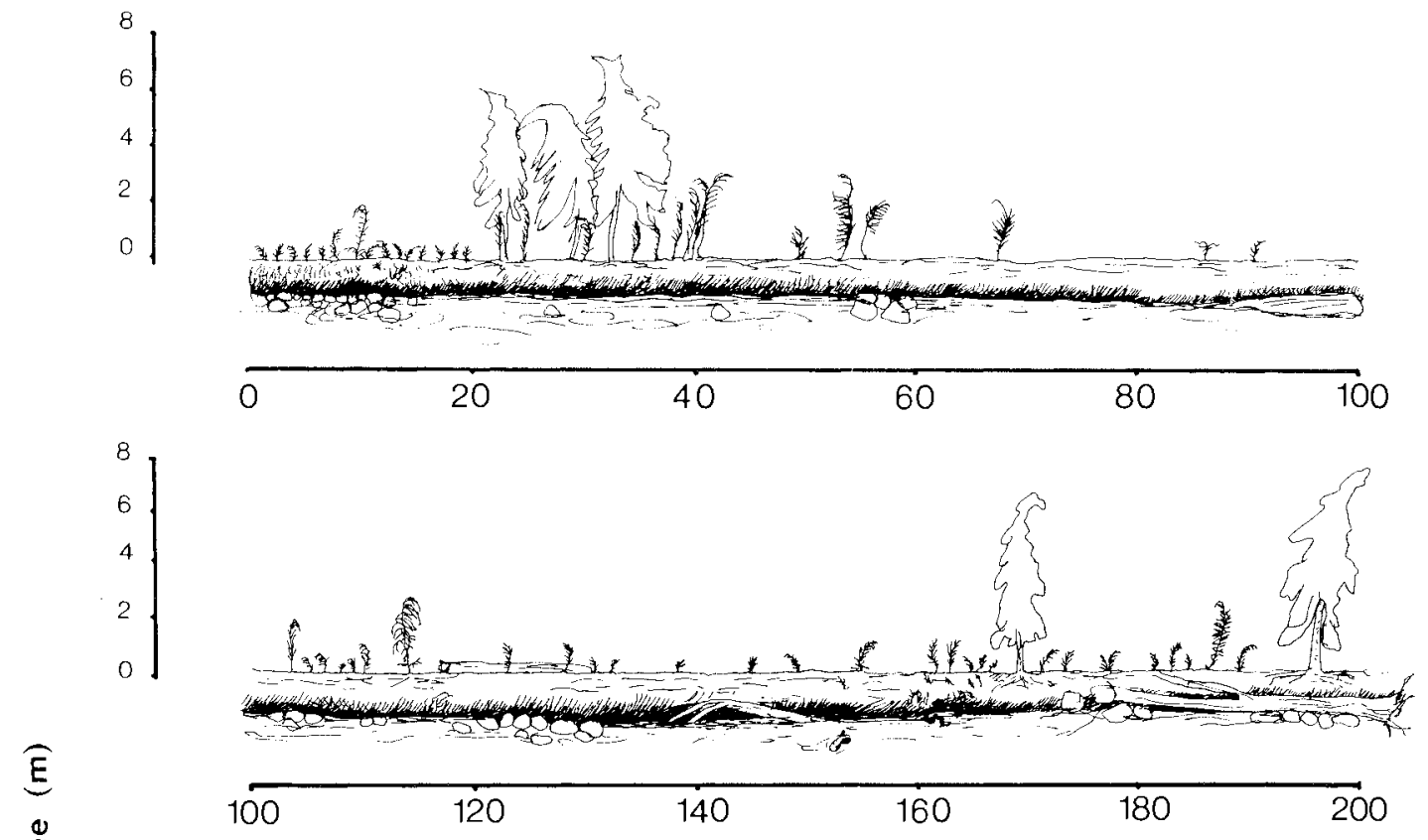

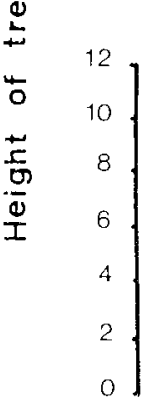
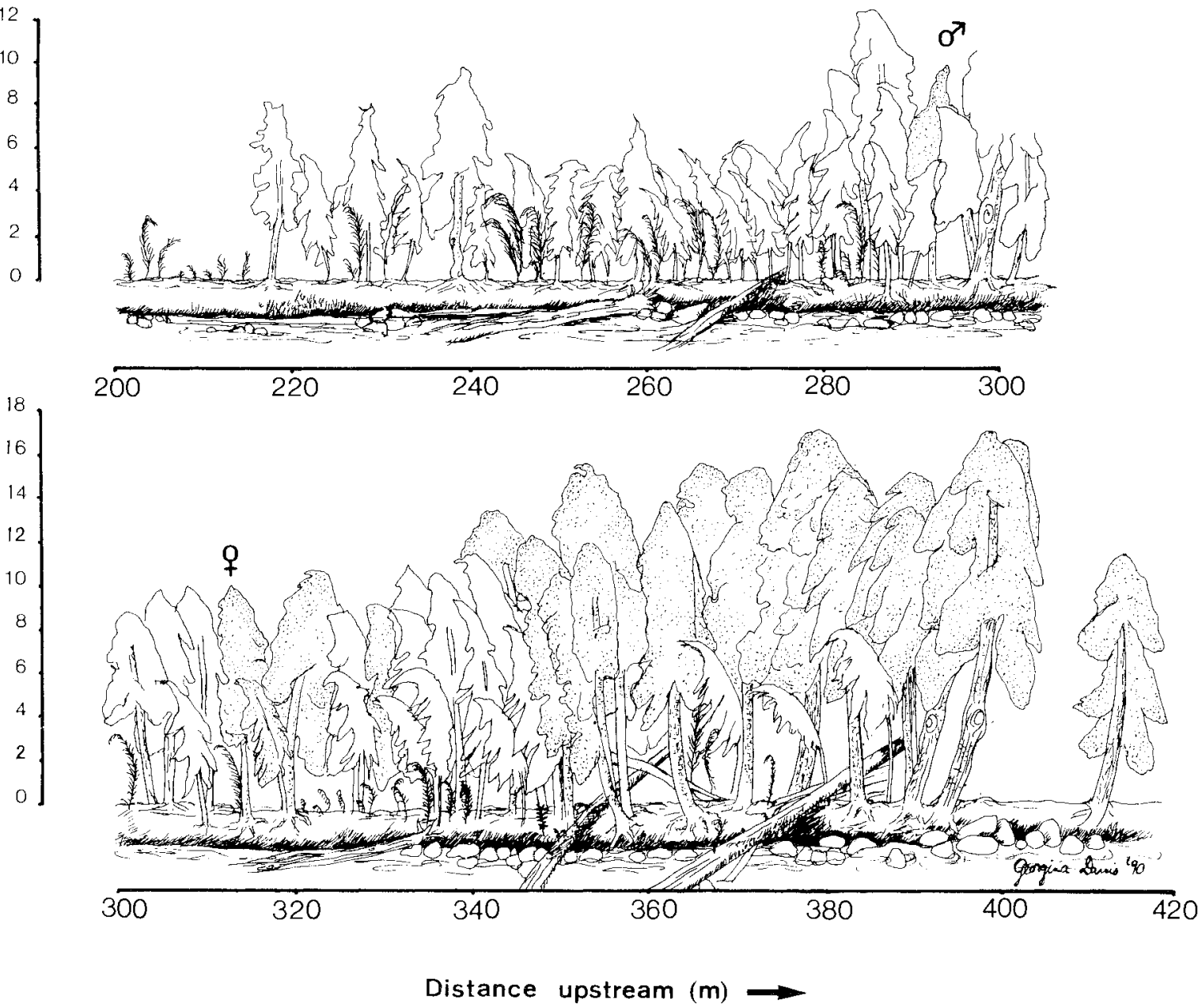

FIG. 7 - The illustration represents a transect of the Huon pine population up Condominium Creek from $0 \mathrm{~m}$ to $420 \mathrm{~m} ; 0 \mathrm{~m}$ represents the first occurrence of the Huon pine upstream of its intersection with the Scotts Peak Road and the stand came to a natural end $420 \mathrm{~m}$ from this point. The occurrences of the first reproductively active male $\left(\sigma^{\prime \prime}\right)$ and female $(q)$ trees up the transect are indicated. Only Huon pine plants are represented and, except in the tallest denser section, all plants recorded are illustrated. 


\section{DISCUSSION}

\section{Seedfall}

The results indicate that Huon pine can produce very large numbers of seeds in mass years. The $5 \times 10^{4}$ seeds per $\mathrm{m}^{2}$ compares with some of the higher densities of seedfall reported for other species from a variery of countries in the literature (table 4). The seedfall is greater than that recorded for the other Tasmanian species reported.

Mast seeding is characteristic of the Podocarpaceae as well as many other tree species (Norton et al. 1988). Many authors (e.g. Janzen 1976) suggest that climatic conditions may trigger a mast year and in New Zealand hot dry summers are thought to be a climatic cue (Silvertown 1980, Ogden 1985). Ogden (1985) suggested that periodic massive seeding may be a strategy for keeping safe sites fully stocked with long-lived seedlings and may also provide enhanced opportunity for long-distance dispersal and colonisation of sites which are spatially and temporally restricted. An aiternative hypothesis suggests that synchronous seeding acts to satiate seed predators with an over-abundance of seed and, in addition, prevent predator population growth in intervening years (Janzen 1976, Silvertown 1980, Wardle 1984, Louda 1989). If predator satiation is a factor, trees out of synchrony will be strongly selected against, due to a build up in predator numbers during the mast year (Janzen 1976, Silvertown 1980).

Little is known of seed predators of Huon pine, although the green rosella observations are consistent with predator satiation, since the observed feeding seems to have left large quantities of seed (table 1). The number of birds gathering and feeding on Huon pine at Riveaux Creek was not large and there was limited evidence of green rosella activity in other stands. However, at Riveaux Creek the Huon pine seeds and pollen seemed to provide food over winter, when other seed may have been less abundant.

The climatic conditions previous to the 1988-89 masting year do seem to fit the New Zealand hot dry summer climatic cue. Masting in that season was also observed in the two Tasmanian Athrotaxis species. The development of a consecutive second mast year during 1989-90 in Huon pine is interesting. Consecutive mast years have also been recorded in New Zealand podocarps (Norton et al. 1988, Ogden 1985). Good fruiting was recorded for the other Tasmanian podocarps in the 1989-90 season in Tasmania (P.B. Tomlinson, pers. comm.). Continued monitoring indicated that very little seed was set, suggesting the female cone development was out of synchronisation at Riveaux Creek. Very few female cones developed the following season.

The seed matured and was shed over an extended period of time. It has been suggested that an extended period of seed/fruit maturation may be advantageous to animal (e.g. bird) dispersal of seed (Janzen 1983). As Janzen also pointed out, although much seed is likely to be destroyed in the gut, some may pass through intact and, depending on the habits and nature of the animal, may be dispersed to favourable sites for germination. Green rosellas may act as both predators and dispersal agents of Huon pine, and the pattern of its seedfall may reflect the minimising of predator effects by masting and maximising of dispersal by an extended maturation and seed-shedding period.

\section{Dispersal}

The lateral dispersal by wind is very limited, as evidenced by the seed trap and soil/litter data. The dispersal is similar to other podocarps (Norton et al. 1988) but less than that recorded by Hickey et al. (1982) for other Tasmanian rainforest species. This data supports the view that the limited lateral dispersal of Huon pine increases the time taken for colonisation of surrounding vegetation (Gibson 1986, Millington et al. 1979, Davies 1983). Given that Bioclim data (Gibson 1986) suggests that Huon pine could have a broader habitat range at present, poor lateral dispersal may be an important limiting factor. However, the Condominium Creek example demonstrates that downstream colonisation is slow even where dispersal of seed is good, and many areas of superficially suirable habitat may not be colonised by seed. Other authors have speculated, however, that on larger rivers, vegetative material carried by flood waters may disperse the species (Pedley et al. 1980). My studies have indicated that most regeneration is due to vegetative growth from root suckers or fallen or submerged limbs or seedlings. Only very rarely was there evidence of vegetative propagation or potential for it from separated shoots or branches. Davies (1983) noted the patchy Huon pine occurrence on the Denison River and suggested it may coincide with limestone rock types. However, rock types do not explain the conditions at Condominium Creek. Fire may partly explain the pattern of Condominium Creek but other factors such as seedling establishment require further examination.

The amount of seed retrieved from soil samples indicates the size of the soil seed bank and gives an indication that most seed was lost from the soil within a few months of falling. Baker (1989) has found that seed of some species from moist habitats survives better if kept moist. It is possible that Huon pine seeds remaining in moist locations could remain viable, and the seeds may germinate over an extended period of time. Thus, in non-mast years, seeds from the previous season may germinate when favourable conditions occur. There is some evidence for this, since small numbers of cotyledon-size seedlings were found at several sites during the study. These must either have resulted from limited "off season" seedfall, remained at cotyledon stage for several years or germinated after the major seedfall and subsequent germination "wave".

\section{Germination and Establishment}

The germination experiments demonstrated that germination can occur over an extended period of time. The low germination success may be due to inviability and the complex factors affecting dormancy. The germination in the glasshouse experiments began considerably earlier than in the field, probably due to the warmer growth conditions. The success of the "soil" treatment suggests that elements present in this medium may enhance germination. The success of the "soaked" seeds also indicates the role water may play in enhancing germination. The germination success of seeds soaked for two months during the flotation experiment supports this view and may suggest that seeds which are water dispersed may have a greater chance of successful germination than seeds laterally dispersed by wind. The germination in the field at the same time over two consecutive years and the germination with natural light conditions in the glasshouse 
indicate that daylength may trigger a break in dormancy.

The flotation capabilities of Huon pine seeds shown in figure 5 appear far greater than those reported for other podocarps (Ogden 1985), the most buoyant being the smallseeded ones which are reported to be "buoyant until the waxy coat becomes wetted by turbulence" (Preest 1963). The long flotation period coupled with the large numbers of seed falling directly into water, make the potential water dispersal of Huon pine seeds enormous. This form of dispersal is limited to the floodline or directly to the edge of water courses. The Condominium Creek example shows that even with this good seed dispersal, expansion of this stand $400 \mathrm{~m}$ downstream appears to have taken at least 200 years and possibly 400 years or longer, based on stem diameter measurements and average diameter increments (Gibson 1986).

Many of the seedling sites on soil (table 3 ) were observed to be on "mossy mounds", which may be the more stable sections of the bank and consequently less prone to erosion due to flooding. The data on seedling subsrrates demonstrates that logs are not the najor germination site, as they are reported to be in other habitats and for other species (Harman \& Franklin 1989, Read \& Hill 1983). It has been pointed out by Harman \& Franklin (1989) that, even where logs do form the major germination sites, these sites are not necessarily suitable for establishment of mature trees, due to competition between trees and the inadequacy of the substrate for larger root penetration. This view contrasts with that of Read \& Hill (1983), who suggested that, in regenerating forests, logs may provide "competition free" sites.

Playford and Detman (1979) have suggested from pollen data that Huon pine may have been much more widespread in the Tertiary. MacPhail (1979) and Colhoun \& van de Geer (1987) have suggested that Huon pine survived the last glaciation in isolated refugia, and that the present distribution has expanded from these refugia. Macrofossil evidence does not support the view of widespread Huon pine distribution during the Tertiary (Wells \& Hill 1989, Hill \& MacPhail 1985, Hill 1990). Hill (1990) suggests that fossil pollen from the Tertiary may belong to a suite of Podocarpaceae species which pre-dated or were more abundant than Huon pine. Even if the past climate allowed an expanded distribution, range extensions, particularly uphill and away from rivers, would have taken extremely long periods of time. The origins of isolated high altitude sites such as at Lake Vera, Mt Read and Greystone Bluff have not, in my view, been satisfactorily explained, although green rosellas or their predecessors may have played an important role.

\section{Conservation and Management}

Huon pine has been singled out by the general community as an individual species worthy of specific conservation. In addition to the general conservation of its representative community types as outlined by Gibson (1986), this study has identified strategies based on its biology which may help to ensure its long-term survival. Since most effective dispersal appears to be down water channels, stands at the headwaters of catchments may represent stocks from which downstream regeneration may be possible but which would not be restocked if cleared. Thus, they represent key stands to be conserved. In addition, the stands on river flats and away from major stream flow are not likely to be easily regenerated from surrounding stands since lateral dispersal is extremely limited, and these, therefore, should be targeted for conservation. Some of these stands may have arisen from past river courses or flooding and, since many rivers are now controlled by upstream dams, flooding is less likely to provide an appropriate seed source in the future. The stands may represent distinct genetic subsets, due to their isolation from orher stands, and so may be worthy of protection for this reason also. Riverbank integrity is important for the germination and establishment of seedlings, as most seedlings have been found on soil, sand and mossy mounds and most trees are found along river edges. Acrivities which degrade river banks will consequently reduce the survival of Huon pine. For example, continual deposition of material can smother young plants, and wave action which erodes the bank can undermine root systems and wash away seedlings. Vegetated buffer zones around Huon pine stands, and particularly along water courses, would also be beneficial since they will protect against fire and allow establishment of seedlings and saplings of Huon pine by maintaining a more constant moist environment.

\section{ACKNOWLEDGEMENTS}

I wish to thank G.L. Davis for field assistance and artwork for figures and also J. Reid, M. Brown, J. Kirkpatrick, J. Balmer, J. Hickey, S. Harris and R. Wiltshire for help with the design of the project and for technical or manuscript assistance.

\section{REFERENCES}

BAKER, H.G., 1989: Some aspects of the natural history of seed banks. In Leck, M.A., Parker, V.T. \& Simpson R.C. (Eds): ECOLOGY OF SOIL SEED BANKS. Academic Press, New York and London: 9-21.

Baliardie, R.T. \& Whelan, R.J., 1986: Masting, seed dispersal and seed predation in the Cycad Macrozamia communis. Oecologia 70: 100-105.

Berrigan, S.J., 1982: Research of seed scatter of King Billy Pine. Unpubl. report, Forestry Commission, Tasmania.

BRown, P., 1984: Food and feeding of the Green Rosella. Tasmanian Bird Report 13: 17-24.

Colhoun, E.A. \& VAN DE Gier, G., 1987: Vegetation history and past climate before the maximum of the last glaciation at Crotty, Western Tasmania. Pap. Proc. R. Soc. Tasm. 121: 69-74.

Davies, J., 1983: HUON PINE SURVEY. Div. Wildl. Tech. Rep. 83/2. National Parks and Wildlife Service, Tasmania.

Francfy, R.J., BarbetTi, M. \& Biri, T., et al., 1984: ISOTOPES IN TREE RINGS. Tech. Pap. 4. CSIRO Australian Division of Atmospheric Research: 1-86.

GIBSON, N., 1986: HUON PINE CONSERVATION AND MANAGEMENT. Div. Wildl. Tech. Rep. 86/3. National Parks and Wildlife Service, Tasmania.

Gibson, N., 1988: A description of the Huon Pine (Lagarostrobos franklinii (Hook. f.) C.J. Quinn.) forests of the Prince of Wales and King Billy Ranges. Pap. Proc. R. Soc. Tasm. 122(2): 127-133.

Harman, M.E. \& Frankin, J.F., 1989: Tree seedlings on logs in Picea-Tsuga forests of Oregon and Washington. Ecology 70(1): 48-59.

Hickey, J.E., Blakesly, A.J. \& Turner, B., 1982: Seedfall and germination of Nothofagus cunninghamii (Hook.) Oerst. Eucryphia lucida (Labill.) Baill. and Atherosperma moschatum Labill. Implications for regeneration practice. Aust. For. Res. 13: $21-28$ 
Hit., R.S., 1990: The fossil history of Tasmania's rainforest tree species. Tasforests $2(1): 5-12$.

HIL, R.S. \& MACPIAII, M.K., 1985: A fossil flora from rafted pliopleistocene mudstones at Regarta Point, Tasmania. Aust. J. Bot. 33: 497-517.

Howard, T.M., 1973: Studies in the ecology of Nothofagus cunninghamii Oerst. II. Phenology. Aust. J. Bot. 21:79-92.

JAN Zn, D.H., 1976: Why do bamboos wait so long to flower? Ann. Rev. Ecol. Syst. 7: 347-391.

JAN Jin, D.H., 1983: Dispersal of seeds by vertebrate gurs. In Futyama, D.J. \& Slatkin, M. (Eds.): COEVOLUTION. Sinauer Associates, Sunderland, Mass.: 232-262

LOU:3A, S.M., 1989: Predation in the dynamics of seed regeneration. In Leck, M.A., Parker, V.T. \& Simpson, R.L. (Eds.): ECOLOGY OF SOIL SEED BANKS. Acadenic Press, New York and London: 25-49.

MacPhall, M.K., 1979: Vegetation and climates in Southern Tasmania since the lasc glaciation. Quaternary Research 11: 306-341.

Miz IINGTON, R.J., Jonfes, R., Brown, D. \& Verivon, B., 1979: HUON PINE - ENDANGERED? Univ. Tasm. Environ. Stud. Occ. Pap. 9.

Norron, D.A., Herrert', J.W. \& Bevipider, A.E., 1988: The ecology of Dacrydium cupressinum: a teview. N. Z. J. Bot. 26: $37-62$

O'DowD, D.J. \& GIl., A.M., 1984: Predator satiation and site alteration following fire: mass reproduction of alpine ash (Eucalyptus delegatensis) in Southeastern Australia. Ecology 65(4): 1052-1066.

OGIJEN, J., 1985: An introduction to plant demography with special reference to New Zealand trees. N.Z. J. Bot. 23: 751-772.
Pholfy, I., Brown, M.J. \& Jarman, S.J., 1980: A SURVEY OF HUON PINE IN THE PIEMAN RIVER STATE RESERVE AND ENVIRONS. Wildl. Div. Tech. Rep. 80/2. National Parks and Wildlife Service Tasmania.

Ptitrson, M.]., 1990: DISTRIBUTION AND CONSERVATION OF HUON PINE. Forestry Commission, 'Tasmania.

Playpord, G. \& Ditman, M.E., 1979: Pollen of Dacrydium franklinii Hook. f. and comparable early Tertiary microfossils. Pollen et Spores 20: 513-534.

PRFEST, D.S., 1963: A note on the dispersal characteristics of the seed of the New Zealand podocarps and beeches and their biological significance. In Gressit, L.S. (Ed.): PACIFIC BASIN BIOGEOGRAPHY. 10th Pacific Science Congress, Honolulu, Hawaii, 1961. Bishop Museum Press: 415-424.

QunN, C.J., 1982: Taxonomy of Dacrydium Sol. ex Lamb. amend de Lamb. (Podocarpaceae). Aust. J. Bot. 30: 31 1-320.

RliAD, I. \& H11., R.S., 1983: Rainforest invasion onto Tasmanian old-fields. Aust. I. Ecol. 8: 149-161.

Shapcotr, A., 1991: Studies in the population biology and genetic variation of Huon pine (Laqarostrobus franklinit). NRCP Tech. Rep. 4. National Rainforest Conservation Program and Department of Parks, Wildlife and Heritage, Hobart, and Department of the Arts, Sport, the Environment and Territories, Canberra.

SirvtrRTOWN, J.W., 1980: The evolutionary ecology of mast seeding in trees. Biol. J. Linnean. Soc. 14: 235-250.

WARIDE, J.A., 1984: The New Zealand beeches, ecology utilisation and management. New Zealand Forest Service.

Well.s, P.M. \& Hill, R.S., 1989: Fossil imbricate-leaved Podocarpaceae from Tertiary sediments in Tasmania. Aust. Syst. Bot. 2: 387-423.

(accepted 3 May 1991) 